\title{
Understanding Civil Servants Readiness to Work from Home: The Roles of Demographic Factors
}

\author{
Dyah Ayu Febriani \\ Faculty of Administrative Science, Universitas Indonesia (Email: dyah.ayu76@ui.ac.id) \\ Fitria Ariyanti \\ Faculty of Administrative Science, Universitas Indonesia (Email: fitriariyanti@ui.ac.id) \\ Reza Fathurrahman \\ Faculty of Administrative Science, Universitas Indonesia (Email: rezafathurrahman@ui.ac.id)
}

\begin{abstract}
This study investigates the roles of four demographic factors, namely the types of position held, age, educational level, and length of work, behind civil servants' readiness to work from home by employing the Readiness for Organizational Change Theory (Holt et al, 2007). Primary data $(n=383)$ were collected from online survey with non-probabilistic sampling. The results from linear regression analysis show that individual working position, age, and educational level significantly impact their readiness to carry out telework effectively. This finding may serve as a basis for policymakers in designing proper work-from-home policies and procedures for civil servants in the future. Nevertheless, follow-up studies with different designs, theoretical frameworks, and more diverse respondents are encouraged to better understand these early findings.
\end{abstract}

\section{Keywords:}

civil servants; readiness for change; teleworking; work from home

\section{Introduction}

In early 2020, various countries around the world are facing a Covid-19 pandemic which not only destabilizes the health sector, but also has a sustainable effect on the social, economic, and state of a country (Ritchie \& Roser, 2020). Various countries in the world are required to be able to face this pandemic even with limited information and many uncertainties. In facing this situation, a country must be able to act agile and adaptive, especially in terms of appropriate and appropriate policy making, the existence of a degree of centralization of decisions, autonomy of decisions, to create a balance between the central and regional governments in the face of this pandemic in order to respond responsively and well. for all changes that occur in the environment (Janssen \& Voort, 2020). 
While facing this condition, it is very important for the government to be able to respond to various forms of changes that occur in the environment accompanied by accurate, useful and up-to-date information to the public by using various social media and digital platforms as well as providing excellent service to the despite with all the existing limitations (TheAsean, 2020). The government is expected to be able to make adjustments and adaptations to face this pandemic, this also applies to the Indonesian government. Stability and adaptation to deal with this pandemic are contradictory, but both are urgently needed (Jansen \& Voort, 2016). Adaptation that changes should be made by the government while facing environmental changes, but with a note that stability must be maintained in carrying out the processes within the bureaucracy itself (Bronen \& Chapin, 2013).

In the middle of this pandemic, the government is expected to be able to provide optimal and prime services even though minimizing face-to-face services. In Indonesia, the Covid-19 pandemic is considered a momentum in optimizing the implementation of bureaucratic reform, one of which is so that Civil servants (CIVIL SERVANTS) are able to adapt and improve their abilities so that bureaucratic services remain optimal by doing work and providing services digitally (tanotofoundation.org, 2020). The Indonesian government itself has a short-term strategy to make the bureaucracy effective, namely by implementing digital bureaucracy, standardization of services, and professionalism of human resources where digital bureaucracy is considered very much needed during the Covid-19 pandemic itself to maintain the performance of civil servants and become the best way of service. to the community (KASN.go.id, 2020). The existence of digitalization in the bureaucracy is one of the transformations towards virtualization which is a result of one of the megatrends, namely decentralization and location independence that allows work and services to be carried out remotely with the internet revolution and remote working to support employees to work more flexibly which is known as teleworking (Stratigea \& Giaoutzi, 2000; Caillier, 2012).

The existence of a teleworking concept with home-based telework work or work from home previously has also been proposed and planned from the Ministry of Administrative Reform and Bureaucratic Reform (PANRB) for civil servants before this pandemic occurs (Fajar, 2019). The Covid-19 pandemic has become one of the factors in the acceleration of the realization of home-based telework for civil servants where the Ministry of PAN issues instructions to work from home as stated in the Circular Letter of the Minister of PAN-RB No. 
50 of 2020 concerning the Second Amendment to the Circular Letter of the Minister of PANRB No. 19 of 2020 concerning Adjustments to the ASN Work System in Efforts to Prevent the Spread of Covid-19 in Government Agencies. In this instruction, KemenPANRB also instructs that every civil servant compile a fiber work plan to carry out official duties according to the given performance targets and targets then make regular performance reports so that they remain productive and have high performance while working from home (KASN.go. en, 2020).

Work from home (WFH) instruction is one of the changes that occur in Indonesian bureaucracy which relies on the ability and competence of civil servants to change and follow these changes, especially by utilizing technology in running the bureaucracy and still providing excellent service to the community (Mariskan, 2020). However, changes in the work patterns of civil servants within the WFH system are not automatically accepted and implemented properly by all civil servants in Indonesia, it requires personal commitment, knowledge, and supporting facilities such as the availability of internet networks and supporting devices to generate productivity and do not forget to be expected to be able to keep emotions while running WFH (palembang.bkn.go.id, 2020; KPMG, 2020). This is important so that civil servants can continue to carry out their jobs despite changes in the way they work from home.

As long as WFH is implemented, civil servants are in a doubtful performance, according to KASN there are a number of delays in public services that occur as a result of the WFH policy being implemented suddenly as part of preventing the transmission of covid-19, because a number of civil servants need adaptation time in using the online system which is new for ASN (Cahyana, 2020). In the other hand, KemenPAN-RB as quoted in detik.com, stated that at the time of WFH there were many civil servants who were not productive, especially civil servants who were not adaptive to the use of technology, namely civil servants aged 50 and over or identical to civil servants who held structural positions and There are many employees who are not in accordance with the required competencies, so one of the temporary solutions is to move to another position (Lidyana, 2020). Thus, readiness is needed in implementing WFH, because civil servants are not fully able to perform well while implementing WFH. 
In line with prior explanation, several studies state that there are several facts that cause the teleworking policy to not work properly when applied to civil servants, including technology, regulations regarding civil servant discipline that are unclear and not well communicated and the low quality of civil servants. itself (Suarlan, 2017). Regarding the quality of civil servants, in fact, training and education programs can be a solution for improving the quality of civil servants, especially in Indonesia, but another problem arises when most of the civil servants in Indonesia are high school graduates and are around 46-55 years old which causes them to think that the training provided especially for implementing teleworking activities is not needed because they think that their professional career will end soon and retire, this is a consideration that the implementation of teleworking will not optimally functioned in Indonesia in the near future (Suarlan, 2017). In line with this, it was also found that younger workers tend to be more consistent in carrying out teleworking which values more about the telework and considers that this method of work is an convenience and has more freedom to plan time and work independently as desired while still paying attention to the quality of the work (Fonner \& Roloff, 2010; Nakrošienè, Bučiūnienė, \& Goštautaitè, 2019).

Several studies on teleworking also show that the higher the level of education, the employees will choose to work from home. One of the results from the research of Walls, Safirova, and Jiang (2010) shows that education has a strong positive impact on the tendency to work from home, especially people with higher educational achievement. In line with this, Drucker and Khattak (2000) quoted by Walls, Safirova, and Jiang (2010), stated that the higher the level of education a person has and as he gets older/become senior the more likely he is to work at home. Sigh et al (2013) in their research also stated the same thing, namely that individuals with higher levels of education have higher negotiation and influencing ability with their employers, so they have the readiness to telecommute and adopt telecommuting. Research by Rupiettaa and Beckmannb (2016), also shows the same thing as previous research, stating that employees who have better education and higher income, more often decide to work from home. Furthermore, research by Bick, Blandin and Mertens (2020) shows that during the month of May 2020 there were more than half (50.2 percent) of all workers with a bachelor's degree or more (higher education) working from home every day, whereas only 
14, 6 percent of workers with a secondary school degree or less (low education) work from home.

Position is also one of the factors in doing work from home, because the position includes the roles, tasks and functions that a person will perform in doing his job. Role theory states that a role is a set of tasks, obligations and expectations related to an individual's position and status (Martin and Wilson, 2005 in Zhang, et al, 2020). Furthermore, Rakhmawanto (2007) states that a position is a collection of work tasks performed by an employee in carrying out his duties, including obligations, responsibilities, and necessary conditions. In line with this, Vries, Tummers, \& Bekkers, 2018 in their research stated that a person's position in an organization can influence their views. Pfeffer (1992) cited by Vries, Tummers and Bekkers (2018), specifically emphasizes position as a very important formal resource because people can have power as a consequence of their formal position in the organizational hierarchy.

Based on several previous studies, the author of this article will elaborate on four demographic factors (length of work, age, education level and position), especially in the public sector in Indonesia. This elaboration is also based on Civil servants act number 5 of 2014. Each demographic factor is further regulated in this Law. Regarding positions, it is regulated more clearly in Article 68 paragraph 1, which states that CIVIL SERVANTS are appointed in certain ranks and positions in Government Agencies, so that positions are inherent in CIVIL SERVANTS. Based on Government Regulation of the Republic of Indonesia Number 11 of 2017 concerning Civil Servant Management, position is a position that indicates the functions, duties, responsibilities, powers and rights of an ASN employee in an organizational unit.

According to Holt (2007), readiness itself means that readiness to change is a comprehensive attitude that is simultaneously influenced by content (what is changed), process (how the change is implemented), and context (the circumstances in which the change is taking place, and In line with this, Armenakis et al. (1993) quoted by Rafferty et al. (2013) stated that there are two beliefs as a key component of readiness for change, this component is the belief that change is needed and the belief that individuals and organizations have the capacity to make change In line with this, Bernerth (2004) states that readiness is more than just understanding change, readiness is more than simply believing in change, readiness is a 
collection of thoughts and intentions towards certain change efforts. then readiness is an important thing ng owned by civil servants in making changes, especially changes that must be implemented during the pandemic that hit the whole world, including Indonesia. Looking at various previous statements, the readiness of civil servants is the main thing in change, because civil servants must still be able to provide services in various existing situations. In line with this, Armenakis, Harris, and Mossholder (1993) argue that creating readiness is often linked to the relationship as a way to reduce resistance to changes that occur. Readiness is also often described in terms of the beliefs, attitudes and intentions of organizational members (Armenakis, Harris, and Mossholder, 1993), so that it is an important thing because it includes the attitudes and intentions of organizational members in making change. Furthermore, readiness is needed because it is one of the most important factors involved in early support for change initiatives (Armenakis et al., 1993; Armenakis, Harris, \& Feild, 1999 in Holt, et al, 2007).

Furthermore, Holt (2007) states that there are four dimensions that are used to measure readiness for change. The first dimension, Appropriateness, which refers to the level of individual confidence that the proposed changes are appropriate, necessary, and beneficial for the organization, which consists of two indicators, namely Discrepancy (the level of individual confidence that change initiatives are needed because it is a need and there are legitimate reasons for taking the initiative. on these changes) and Organizational Valence (the level of individual confidence that changes will benefit the organization). The second dimension, Management support, refers to the level of individual belief that the leader in the organization is committed to and supports the implementation of change. The third dimension is Change-Specific Efficacy which refers to the level of individual belief that they have the ability and skills to carry out tasks and activities when change is implemented. The last or fourth dimension is Personal Valence which refers to the level of individual confidence that the proposed changes are beneficial for the individual personally.

In line with prior explanation, it can be seen that the first dimension represents the Change Content perspective in the individual readiness model, the second dimension represents the Change Process perspective in the individual readiness model, because the role of the leader is closely related to the steps taken during the change, as well as the third dimension and the fourth represents the perspective of Individual Attributes in the readiness 
model related to individual characteristics in the organization. These four dimensions are the focus used by the authors in this article to see the readiness of civil servants in Indonesia based on their positions in implementing WFH. Based on the problem description and literature review that has been described by the author above, the writer using Holt's main theory as a measurement tool in seeing the readiness of civil servants based on their position in implementing WFH, will raise the main research question, namely: Is the level of civil servant readiness influenced by position (structural / Functional), Education Level, Age, and Job Tenure?

\section{Methods}

This study uses a quantitative approach using online survey questionnaire design to measure the readiness of civil servants in carrying out WFH policies. The purpose of this study was to see the differences in the readiness of civil servants in structural and functional positions, age, last education, and job tenure in carrying out WFH policies both in the central government and local governments based on the theory of readiness for organizational change proposed by Holt, Armenakis, Field, and Harris (2007) with four dimensions of readiness; suitability, management support, change-specific efficacy, and personal valency. This research is a descriptive and explanatory research because it is conducted to describe a condition (readiness of civil servants) and to find an explanation of an event, namely between the WFH policy, the position of a civil servant, age, last education, and job tenure. The primary data for this study were taken cross-sectional through an online survey using a monkey survey platform which was conducted on 3rd August to 10th August 2020. The population of this study were civil servants who were divided into two groups, namely structural and functional positions with non-probabilistic sampling, namely quota sampling and there are 383 respondents available (157 respondents from civil servants in structural positions and 226 respondents for functional positions), with proportion of female 195 respondents and male 188 respondents. According to respondents' domicile, most of the respondentss come from West Java Province (130 respondents) and DKI Jakarta Province (113 respondents), so the data does not represent civil servants in general. Data processing used to measure the level of readiness is a likert scale that includes 4 categories (Strongly Agree, Agree, Disagree, and Strongly Disagree), researchers used descriptive analysis techniques by dividing into three 
levels of readiness, namely; low is valued 1 with a score of 10-20; moderate valued 2 with a score of 20.01-30; and high is valued 3 with a score of 30.01-40 (Dittrich, France, Hatzinger, \& Katzenbeisser, 2007). In doing the statistical analysis, the authors used the SPSS software tools. Measurement of the readiness of each position in implementing WFH is done with basic computing. Furthermore, the formula that being used for testing two groups of sample is the multiple linear regression Analysis for calculating the value of a dependent variable (readiness of civil servants in carrying WFH) from an independent variable (structural and functional position, age, last education, and job tenure). The purpose of using the multiple linear regression is to examine if there is any influence between the dependent variable and the 4 independent variables provided.

\section{Results and Discussion}

According to the factual situations on the field that have been previously described regarding the pandemic situation which accelerate the digitalization of public services whose conducted by the civil servants in Indonesia that have been described previously regarding the pandemic situation which is one of the levers for the acceleration of the digitalization of services and the workings of civil servants in Indonesia, researchers will examine the level of readiness of civil servants in conducting WFH by looking at the influence of four demographic factors, namely position (structural / functional), age, education level and length of time working based on data collection that has been done by researchers with a sample of 383 respondentss, consisting of 157 structural positions and 226 functional positions. In this study, the number of female respondents is dominating the survey with 195 respondents while their male counterparts only consist 188 respondents, the data can be referred to Figure 1 below. In line with data from the BKN issued in June 2020, the proportion of women is also more dominant based on gender, with a total of $2,130,961$ or around $51.71 \%$. while the number of male civil servants was 1,990,215 or $48.29 \%$ (BKN, 2020). Furthermore, table 1 shows the results of calculations using ANOVA and regression. Then, the analysis results of the pandemic effect to current situation using multiple linear regression coefficients is displayed in Table 2 
Table 1.

Anova Determinants of Significance of Regression

Model Summary

\begin{tabular}{|l|l|r|r|r|}
\hline Model & $\mathrm{R}$ & R Square & \multicolumn{1}{c|}{$\begin{array}{c}\text { Adjusted R } \\
\text { Square }\end{array}$} & $\begin{array}{c}\text { Std. Error of } \\
\text { the Estimate }\end{array}$ \\
\hline 1 &, $190^{\mathrm{a}}$ &, 036 &, 026 &, 51579 \\
\hline
\end{tabular}

a. Predictors: (Constant), LAMA WAKTU BEKERJA, JABATAN

YANG ANDA MILIKI, PENDIDIKAN TERAKHIR, USIA

Source: SPSS Data Analysis, 2020

Based on table 1, we can see that $3.6 \%$ of civil servants' readiness in implementing WFH is influenced by the length of time worked, their position, last education, and internal age, the rest there are other influences that are not explained in this paper.

ANOVA $^{\mathrm{a}}$

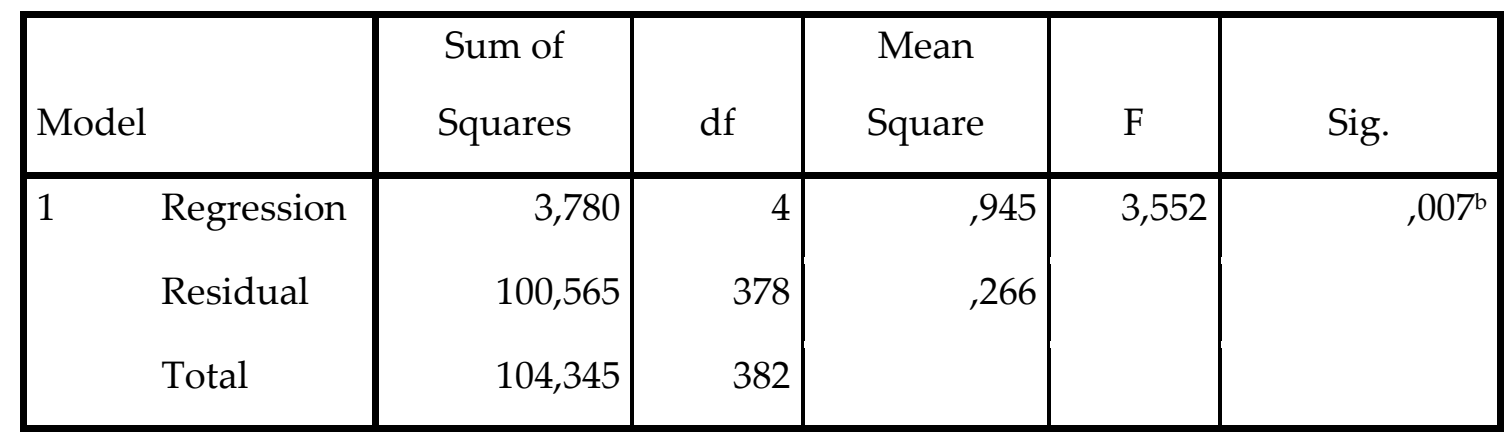

a. Dependent Variable: Tingkat Kesiapan WFH (Revisi - Recode)

b. Predictors: (Constant), LAMA WAKTU BEKERJA, JABATAN YANG ANDA

MILIKI, PENDIDIKAN TERAKHIR, USIA

Source: SPSS Data Analysis, 2020

Table 1 shows that the $\mathrm{F}$ count is 3.552, while the $\mathrm{F}$ table value can be obtained by using the $\mathrm{F}$ table with degrees of freedom (df) Residual (residual) which is 378 as the denominator $\mathrm{df}$ and $\mathrm{df}$ Regression (treatment) which is 4 as the df numerator with significance level of 0.05 . Based on the significant value, it can be seen in the sig column that is 0.007 which means the probability of 0.007 is less than 0.05 , then, the regression equation model based on the research data is significant, meaning that the existing linear regression model with predictor variables is the job tenure, the position held, the last education. , and age can be used to predict the readiness of civil servants to implement WFH policies. 
Table 2.

Multiple Linear Regression Coefficient

Coefficients $^{\mathrm{a}}$

\begin{tabular}{|c|c|c|c|c|c|c|}
\hline \multirow{2}{*}{\multicolumn{2}{|c|}{ Model }} & \multicolumn{2}{|c|}{$\begin{array}{c}\text { Unstandardized } \\
\text { Coefficients }\end{array}$} & \multirow{2}{*}{$\begin{array}{c}\text { Standardized } \\
\text { Coefficients } \\
\text { Beta }\end{array}$} & \multirow[b]{2}{*}{$\mathrm{t}$} & \multirow[b]{2}{*}{ Sig. } \\
\hline & & B & Std. Error & & & \\
\hline \multirow[t]{5}{*}{1} & (Constant) & 2,436 & ,204 & & 11,945 & , 000 \\
\hline & $\begin{array}{l}\text { The position of a civil } \\
\text { servant }\end{array}$ &,- 155 & ,054 &,- 146 & $-2,853$ & ,005 \\
\hline & The last education & ,067 & ,036 & 100 & 1,885 & , 060 \\
\hline & Age &,- 065 &, 034 &,- 132 & $-1,909$ & ,057 \\
\hline & Job Tenure & ,019 & ,042 & ,032 & 457 & 648 \\
\hline
\end{tabular}

a. Dependent Variable: Tingkat Kesiapan WFH (Revisi - Recode)

From Table 2, it shows that three out of four independent variables (position held, age, and latest education) have a significant effect on the readiness of civil servants in implementing WFH. The position variable held has a significant negative effect on the one percent confidence level, meaning that structural positions have better readiness than functional positions. Meanwhile, younger and more educated civil servants respondentss have better readiness than older and less educated civil servants respectively at the ten percent confidence level. Meanwhile, the Variable Length of Working Time has no significant effect on the readiness of civil servants in implementing WFH.

The descriptive analysis of the three variables is explained in succession as in the graph below. 


\section{Graph 1.}

RFC Score by Position

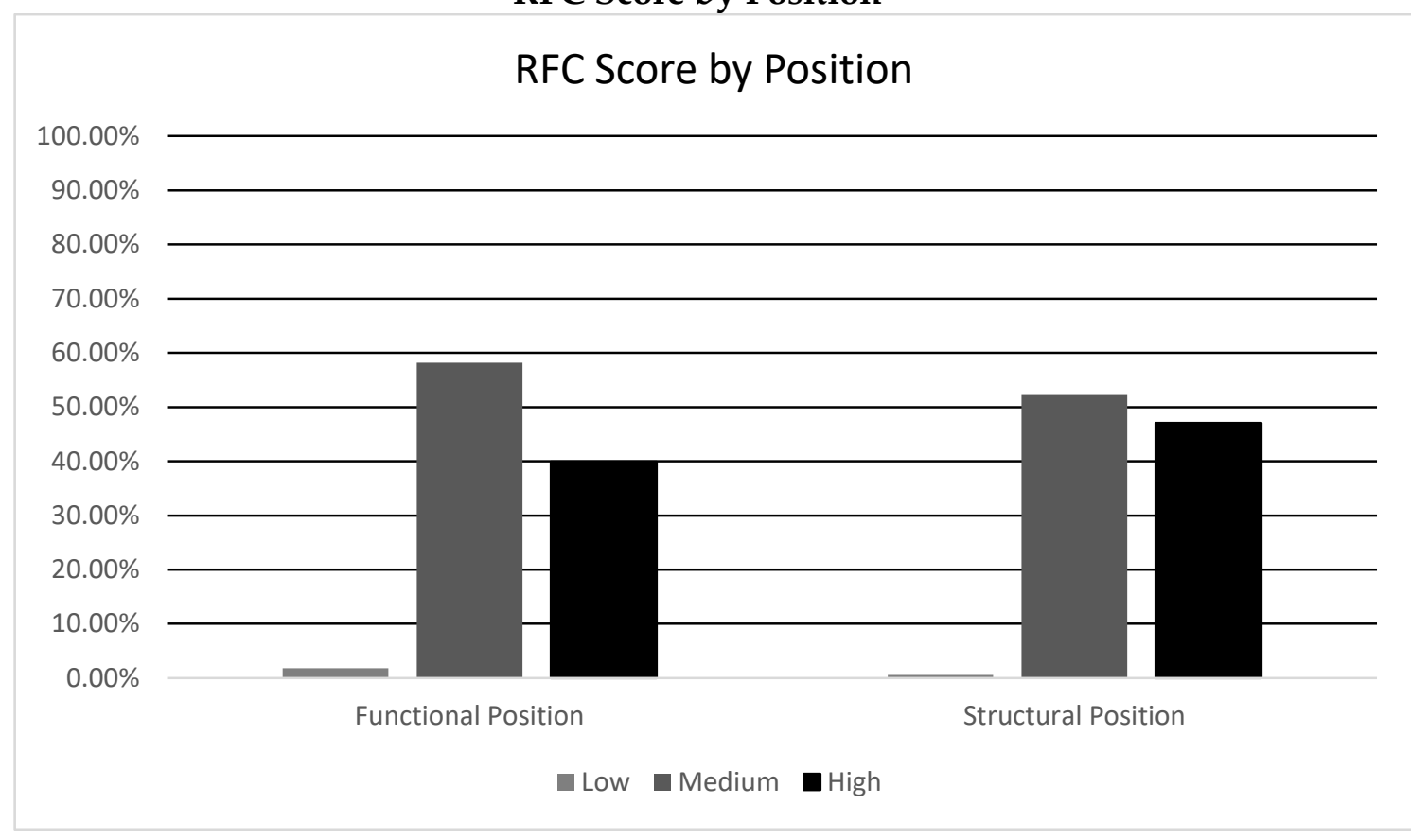

Source: Results of research data processing, 2020

Information $n=383$; functional position $=226$ respondents; structural position $=157$ respondents

According to table 2, the results of linear regression analysis, the occupational variable (functional vs structural) has a significant effect on $1 \%$ in a negative direction In spite of the the fact that the second functional and structural positions are spread into two readiness categories (medium and high), the percentage of respondentss who hold structural positions with a high level of readiness is relatively higher than respondentss who have functional positions (47.1\% versus 39, 9\%). In addition, descriptive analysis at the dimension level shows that the majority of respondentss who have structural positions (50.3\%) consider that they get relatively better support from their superiors than respondentss who have functional positions $(41.4 \%)$. 
Graph 2.

RFC Score by Age

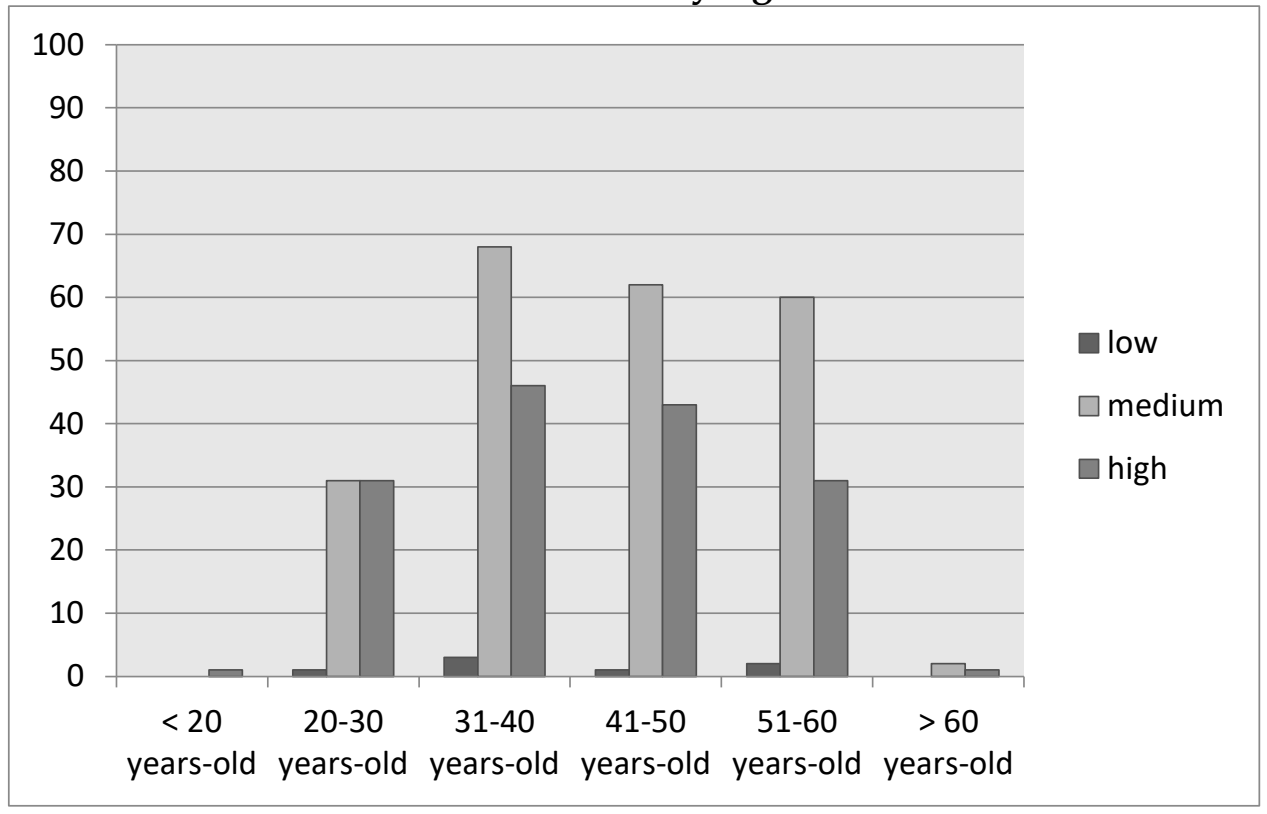

Information: $\mathrm{n}=383$; age $<20$ years $=2$ respondentss; age $20-30$ years $=63$ respondentss; $31-40$ years old $=117$ respondentss; $41-50$ years $=106$ respondentss; and age $>60$ years $=3$ respondentss

Source: Results of research data processing, 2020

Based on table 2 of the results of linear regression analysis, younger civil servant respondentss have a better level of readiness than their older colleagues in welcoming the implementation of WFH policies. As shown in Graph 2 above, civil servants who are in the age range $<20$ have a high RFC score of $100 \%$ ( 2 respondentss). Then, the results of the analysis show that the majority of respondentss at the age of 20-30 have moderate or high readiness (49.5\% respectively). In addition, descriptive analysis at the dimension level shows that the majority of respondentss aged $<20$ years have met three dimensions, namely, the dimensions of Appropriateness, Management Support and Change-Specific Efficacy. This indicates that aged $<20$ feel confident in the urgency of changing their work style from traditional (working from home) to WFH, getting support from their superiors in running WFH and also feeling confident that they have the ability and skills to carry out tasks and activities when the WFH Policy is implemented. As for the 20-30 years old age category, it is only fulfilled in the dimensions of Appropriateness and Management Support, with an indication that at this age 
the urgency of changing work from traditional to WFH and receiving good managerial support is indicated.

\section{Graph 3.}

RFC Score based on Last Education

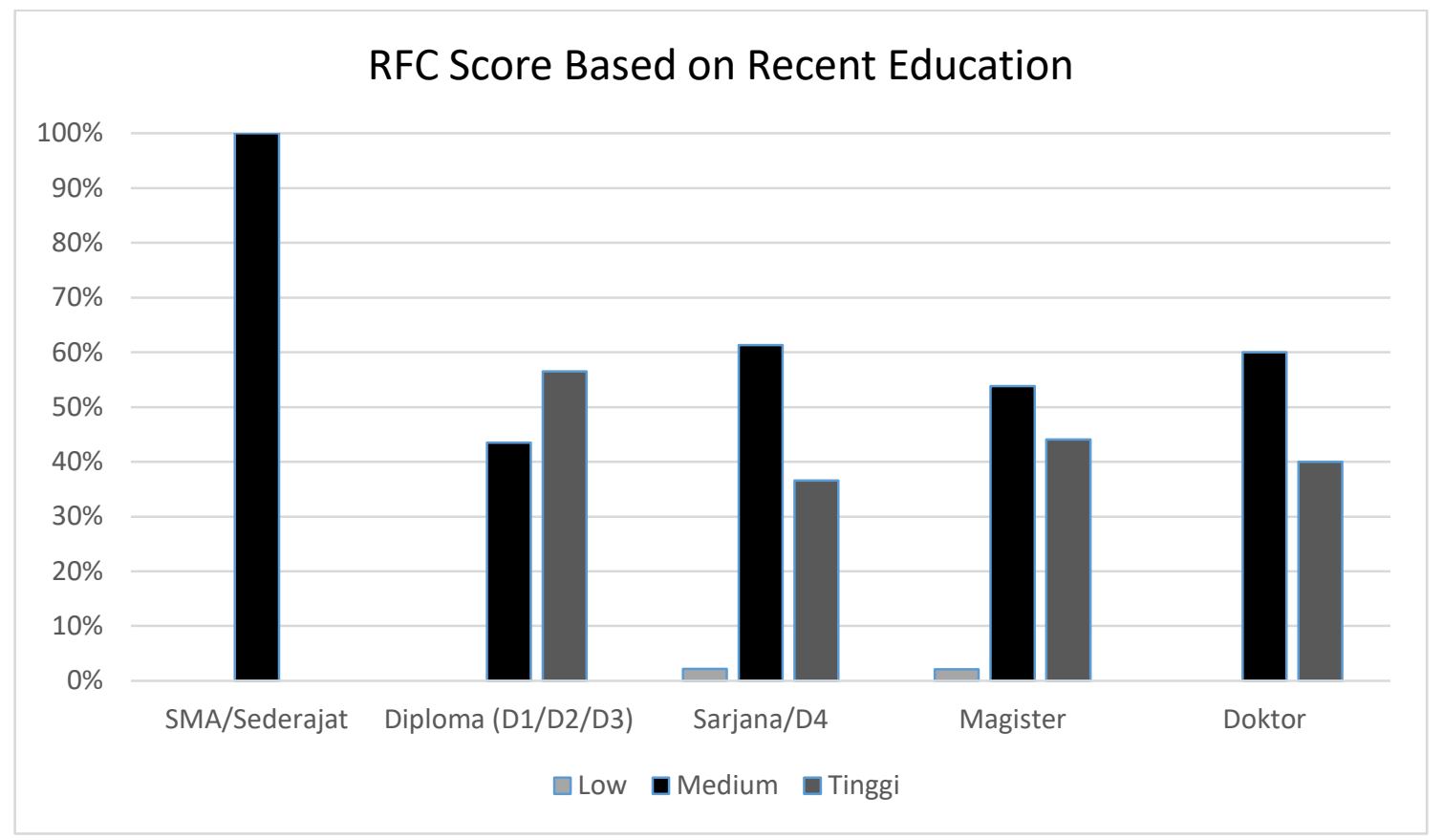

Information: $\mathrm{n}=383$; SMA / equivalent $=9$ respondentss; Diploma $(\mathrm{D} 1 / \mathrm{D} 2 / \mathrm{D} 3)=23$ respondentss; Bachelor / D4 = 186 respondentss; Masters $=145$ respondentss; Doctorate $=20$ respondentss

Source: Results of research data processing, 2020

Furthermore, according to table 2 of the results of the linear regression analysis, education has a significant effect on $10 \%$ with a negative direction where the higher the last education a civil servant has, the higher the readiness to implement WFH. Looking at graph 3 above, although the highest readiness of $100 \%$ is found from SMA / equivalent respondentss, the number of respondentss is only 9 respondentss. Furthermore, by looking at the distribution of the largest respondentss with undergraduate degree (186 respondentss) and "postgraduate/master degree" (145 respondentss), it can be found that the respondentss have moderate readiness or in other words are undergoing a process towards being ready to implement WFH policies when viewed from theory. readiness for change.

Furthermore, to get a more adequate understanding of the results of the above analysis, the researcher conducted further investigations at the dimension level, namely the 
Appropriateness Dimension, Management Support Dimensions, Change Specific Efficacy Dimensions, and Personal Valence Dimensions. These four dimensions will be explained further below;

Table A.

summarizes the results of the descriptive analysis of the Appropriateness Dimensions on the three independent variables (Position, Age, and Education Level)

\begin{tabular}{|c|c|c|}
\hline $\begin{array}{c}\text { Variable of Civil Servants } \\
\text { Position } \\
(\mathrm{n}=383)\end{array}$ & \multicolumn{2}{|c|}{ Readiness Level } \\
\hline \multirow[t]{3}{*}{ Functional Position } & Low & $3,1 \%$ \\
\hline & Medium & $62,4 \%$ \\
\hline & High & $34,5 \%$ \\
\hline \multirow[t]{3}{*}{ Structural Position } & Low & $0,6 \%$ \\
\hline & Medium & $58 \%$ \\
\hline & High & $41,4 \%$ \\
\hline $\begin{array}{l}\text { Variable of Age } \\
\qquad(n=383)\end{array}$ & \multicolumn{2}{|c|}{ Readiness Level } \\
\hline \multirow{3}{*}{$<20$ years } & Low & $0 \%$ \\
\hline & Medium & $0 \%$ \\
\hline & High & $100 \%$ \\
\hline \multirow{3}{*}{ 20-30 years } & Low & $1,6 \%$ \\
\hline & Medium & $46 \%$ \\
\hline & High & $52,4 \%$ \\
\hline \multirow{3}{*}{$31-40$ years } & Low & $1,7 \%$ \\
\hline & Medium & $59 \%$ \\
\hline & High & $39,3 \%$ \\
\hline \multirow{3}{*}{ 41-50 years } & Low & $1,9 \%$ \\
\hline & Medium & $66 \%$ \\
\hline & High & $32,1 \%$ \\
\hline \multirow{3}{*}{$51-60$ years } & Low & $3,2 \%$ \\
\hline & Medium & $66,7 \%$ \\
\hline & High & $30,1 \%$ \\
\hline \multirow{3}{*}{$>60$ years } & Low & $0 \%$ \\
\hline & Medium & $66,7 \%$ \\
\hline & High & $33,3 \%$ \\
\hline $\begin{array}{l}\text { Variable of last education } \\
\qquad(\mathrm{n}=383)\end{array}$ & \multicolumn{2}{|c|}{ Readiness Level } \\
\hline \multirow{2}{*}{ SMA/Sederajat } & Low & $0 \%$ \\
\hline & Medium & $100 \%$ \\
\hline
\end{tabular}




\begin{tabular}{|c|l|c|}
\hline & High & $0 \%$ \\
\hline \multirow{3}{*}{ Diploma (D1/D2/D3) } & Low & $0 \%$ \\
\cline { 2 - 3 } & Medium & $43,5 \%$ \\
\cline { 2 - 3 } & High & $56,5 \%$ \\
\hline \multirow{3}{*}{ Sarjana/D4 } & Low & $2,7 \%$ \\
\cline { 2 - 3 } & Medium & $64 \%$ \\
\cline { 2 - 3 } & High & $33,3 \%$ \\
\hline \multirow{3}{*}{ Magister } & Low & $2,1 \%$ \\
\cline { 2 - 3 } & Medium & $56,6 \%$ \\
\cline { 2 - 3 } & High & $41,4 \%$ \\
\hline \multirow{3}{*}{ Doktor } & Low & $0 \%$ \\
\cline { 2 - 3 } & Medium & $60 \%$ \\
\cline { 2 - 3 } & High & $40 \%$ \\
\hline
\end{tabular}

Source: Results of research data processing, 2020

Based on the processed results of the researcher's survey which can be seen in Table A, functional positions and structural positions have a moderate level of readiness with $62.4 \%$ and $58 \%$ respectively, which means that the two positions are in the process of being ready to implement WFH. Furthermore, the age variable shows that when viewed from the Appropriateness Dimension, readiness is in a high position at $<20$ years old with a percentage of $100 \%$ (1 respondents), $20-30$ years old with a percentage of $52.4 \%$ (33 respondentss), and at other ages are at a moderate level of readiness. In addition, in the last education level variable, high readiness in the appropriateness dimension was shown in Diploma education (D1 / D2 / D3) with a percentage of $56.5 \%$ (13 respondentss), while the majority of readiness viewed from the appropriateness dimension was at a moderate level both at education level Bachelor / D4 ( $64 \%$ or 62 respondentss), master $(56.5 \%$ or 82 respondentss), and doctorate $(60 \%$ or 12 respondentss).

This dimension of appropriateness itself means that there is confidence in the individual if a change made is the right way to solve the problem at hand where this change is considered necessary and useful. This dimension consists two indicators, namely; 1 . Discrepancy (the level of individual confidence that change initiatives are needed because it is a necessity and there are legitimate reasons to initiate these changes) and Organizational Valence (the level of individual confidence that changes will benefit the organization (Holt, Armenakis, Feild, and Harris, 2007)

Most of the respondentss show a positive response with the change in the way of working for civil servants where the respondentss considered that the WFH way of working 
had an effect on the completion of the respondents's work in terms of the effectiveness of the work time and the flexibility in completing the work. Furthermore, this positive response also present because the institution where the respondents works provides website facilities or digital supporting applications that are able to be used by respondentss to facilitate their work during WFH. This positive result was also supported by a statement from the Minister for Administrative Reform and Bureaucratic Reform, Tjahjo Kumolo, that each agency must still be able to provide excellent service to the public even though WFH system is being implemented where each agency is required to have an online attendance application, digitizing services for the community. web-based or application followed by simplification of business processes and supported by standard operating procedures so as to make it easier for bureaucrats and the public (Sugianto, 2020; menpan.go.id, 2020). Furthermore, in other studies said that there is a need for directed regulation regarding WFH itself by looking at the indicators and conditions that make this policy develop by not only paying attention to conditions in the city center (Hynes, 2014).

Table B.

Summarizes the results of the descriptive analysis of the Management Support Dimensions for the three independent variables (Position, Age, and Education Level)

\begin{tabular}{|c|c|c|}
\hline $\begin{array}{l}\text { Variable of Civil Servants } \\
\text { Position } \\
(\mathrm{n}=383)\end{array}$ & \multicolumn{2}{|c|}{ Readiness Level } \\
\hline \multirow[t]{3}{*}{ Functional Position } & Low & $2,7 \%$ \\
\hline & Medium & $54,4 \%$ \\
\hline & High & $42,9 \%$ \\
\hline \multirow[t]{3}{*}{ Structural Position } & Low & $0 \%$ \\
\hline & Medium & $49,7 \%$ \\
\hline & High & $50,3 \%$ \\
\hline $\begin{array}{c}\text { Variable of Age } \\
(n=383)\end{array}$ & \multicolumn{2}{|c|}{ Readiness Level } \\
\hline \multirow{3}{*}{$<20$ years } & Low & $0 \%$ \\
\hline & Medium & $0 \%$ \\
\hline & High & $100 \%$ \\
\hline \multirow{3}{*}{$20-30$ years } & Low & $3,2 \%$ \\
\hline & Medium & $44,4 \%$ \\
\hline & High & $52,4 \%$ \\
\hline
\end{tabular}




\begin{tabular}{|c|c|c|}
\hline \multirow{3}{*}{$31-40$ years } & Low & $3,4 \%$ \\
\hline & Medium & $58,1 \%$ \\
\hline & High & $38,5 \%$ \\
\hline \multirow{3}{*}{$41-50$ years } & Low & $0 \%$ \\
\hline & Medium & $52,8 \%$ \\
\hline & High & $47,2 \%$ \\
\hline \multirow{3}{*}{$51-60$ years } & Low & $0 \%$ \\
\hline & Medium & $66,7 \%$ \\
\hline & High & $33,3 \%$ \\
\hline \multirow{3}{*}{$>60$ years } & Low & $0 \%$ \\
\hline & Medium & $66,7 \%$ \\
\hline & High & $33,3 \%$ \\
\hline $\begin{array}{l}\text { Variable of last education } \\
(\mathrm{n}=383)\end{array}$ & \multicolumn{2}{|c|}{ Readiness Level } \\
\hline \multirow{3}{*}{ SMA/Sederajat } & Low & $0 \%$ \\
\hline & Medium & $88,9 \%$ \\
\hline & High & $11,1 \%$ \\
\hline \multirow{3}{*}{ Diploma (D1/D2/D3) } & Low & $0 \%$ \\
\hline & Medium & $47,8 \%$ \\
\hline & High & $52,2 \%$ \\
\hline \multirow{3}{*}{ Sarjana/D4 } & Low & $1,6 \%$ \\
\hline & Medium & $50,5 \%$ \\
\hline & High & $47,8 \%$ \\
\hline \multirow{3}{*}{ Magister } & Low & $2,1 \%$ \\
\hline & Medium & $53,1 \%$ \\
\hline & High & $44,8 \%$ \\
\hline \multirow{3}{*}{ Doktor } & Low & $0 \%$ \\
\hline & Medium & $55 \%$ \\
\hline & High & $45 \%$ \\
\hline
\end{tabular}

Source: Results of research data processing, 2020

According to table B above regarding the readiness of civil servants in implementing WFH in terms of the management support dimension, it can be seen that the variable positions, both functional and structural positions, are at a moderate level of readiness, which means they are ready to carry out WFH. Furthermore, high readiness in the age variable is in respondentss aged $<20$ years with a percentage of $100 \%$ ( 1 respondents) and 20-30 years with a percentage of $52.4 \%$ (33 respondentss), and the rest are at a moderate level of readiness. The third variable, namely the latest education level, shows that the high level of readiness to implement WFH is at the SMA / equivalent education level with a percentage of $100 \%$ (1 respondents) and a Diploma (D1 / D2 / D3) of 52.2\% (12 respondentss), while the level of Bachelor, Master and Doctoral education are at a moderate level of readiness when viewed 
through the management support dimension. This dimension itself indicates the existence of senior leader support, which refers to the level of individual belief that leaders in the organization are able to commit and support the implementation of change (Holt, Armenakis, Feild, and Harris, 2007). In addition, commitment is needed to carry out institutionalization where if there is no clear support from the leadership, it will have implications for the attitudes of individuals in organizations who tend to be skeptical and inactive in making changes (Armenakis, Harris, and Mossholder, 2002).

In line with this, Respondents have the same belief in the commitment of agency leaders in implementing WFH, it is proven by the number of respondentss who get supporting facilities from the institutions where they work, both facilities such as adequate internet data plan, supporting infrastructure, motivation, allocation of funds and training as a form of support for implementing changes to the WFH work system. This is in line with the regulations that have been regulated by the Minister of Administrative Reform and Bureaucratic Reform (PANRB) through Circular (SE) Number 58 of 2020 concerning the Work System for State Civil servants in the New Normal Order (Setkab.go.id, 2020) . In this circular, the government provides infrastructure support and support for human resources by providing facilities through organizations. The data obtained by researchers shows that the facilities provided are in the form of credit and quota subsidies as has been done by the Ministry of Finance for civil servants under its auspices since April 2020 in the form of credit assistance of IDR 150,000 and the nominal value will be increased in 2021 (Salihah, 2020) .

Furthermore, both in functional and structural positions both feel that respondents get motivated from the leader to implement WFH. This is intended so that individuals in the organization do not lose direction and experience demotivation when facing changes in job search through WFH which will have implications for decreased performance (Dewayani, 2020). In line with this, another study states that a leader and his employees must have a high sense of trust when implementing WFH and also the role of the leader to keep in touch by providing direct support and empathy is needed so that employees feel cared for and don't forget their work and become what they want. in carrying out work (Vries, Tummers, \& Bekkers, 2019)

Then, we have Table $\mathrm{C}$ to explain a descriptive analysis of the Dimensions of ChangeSpecific Efficacy on the three variables that affect readiness in implementing WFH. 
Table C.

Dimensions of Change-Specific Efficacy of Three Variables (Position, Age, and Last Education Level)

\begin{tabular}{|c|c|c|}
\hline $\begin{array}{l}\text { Variable of Civil Servants } \\
\text { Position } \\
(\mathbf{n}=383)\end{array}$ & \multicolumn{2}{|c|}{ Readiness Level } \\
\hline \multirow[t]{3}{*}{ Functional Position } & Low & $1,3 \%$ \\
\hline & Medium & $56,6 \%$ \\
\hline & High & $41,2 \%$ \\
\hline \multirow[t]{3}{*}{ Structural Position } & Low & $0 \%$ \\
\hline & Medium & $54,8 \%$ \\
\hline & High & $45,2 \%$ \\
\hline $\begin{array}{l}\text { Variable of Age } \\
(\mathrm{n}=383)\end{array}$ & \multicolumn{2}{|c|}{ Readiness Level } \\
\hline \multirow{3}{*}{$<20$ years } & Low & $0 \%$ \\
\hline & Medium & $0 \%$ \\
\hline & High & $100 \%$ \\
\hline \multirow{3}{*}{$20-30$ years } & Low & $1,6 \%$ \\
\hline & Medium & $52,4 \%$ \\
\hline & High & $46 \%$ \\
\hline \multirow{3}{*}{$31-40$ years } & Low & $0,9 \%$ \\
\hline & Medium & $52,1 \%$ \\
\hline & High & $47 \%$ \\
\hline \multirow{3}{*}{$41-50$ years } & Low & $0,9 \%$ \\
\hline & Medium & $52,8 \%$ \\
\hline & High & $46,2 \%$ \\
\hline \multirow{3}{*}{$51-60$ years } & Low & $2,2 \%$ \\
\hline & Medium & $67,7 \%$ \\
\hline & High & $30,1 \%$ \\
\hline \multirow{3}{*}{$>60$ years } & Low & $0 \%$ \\
\hline & Medium & $33,3 \%$ \\
\hline & High & $66,7 \%$ \\
\hline $\begin{array}{l}\text { Variable of last education } \\
(\mathrm{n}=383)\end{array}$ & \multicolumn{2}{|c|}{ Readiness Level } \\
\hline \multirow{3}{*}{ SMA/Sederajat } & Low & $0 \%$ \\
\hline & Medium & $88,9 \%$ \\
\hline & High & $11,1 \%$ \\
\hline \multirow{3}{*}{ Diploma (D1/D2/D3) } & Low & $0 \%$ \\
\hline & Medium & $56,5 \%$ \\
\hline & High & $43,5 \%$ \\
\hline Sarjana/D4 & Low & $1,6 \%$ \\
\hline
\end{tabular}




\begin{tabular}{|c|l|c|}
\hline \multirow{2}{*}{ Magister } & Medium & $56,5 \%$ \\
\cline { 2 - 3 } & High & $41,9 \%$ \\
\hline \multirow{3}{*}{ Doktor } & Low & $1,4 \%$ \\
\cline { 2 - 3 } & Medium & $52,4 \%$ \\
\cline { 2 - 3 } & High & $46,2 \%$ \\
\hline \multirow{3}{*}{} & Low & $0 \%$ \\
\cline { 2 - 3 } & Medium & $60 \%$ \\
\cline { 2 - 3 } & High & $40 \%$ \\
\hline
\end{tabular}

Source: Results of research data processing, 2020

According to results of the researcher's survey which can be seen in Table C, the Change-Specific Efficacy dimension with its relation to the three variables affecting WFH (position, age, and education level) shows interesting results with an average level of readiness in medium score. In the Position Variable, both (Functional and Structural) are at the medium level in carrying out WFH, namely 141 respondentss (56.6 percent) in Functional Positions and 91 respondents (54.8 percent) in Structural Positions. The age variable shows that those aged $<20$ years and $>60$ years are at a high level of readiness with $100 \%$ (2 respondentss) and $66.7 \%$ (2 respondents) respectively and other age levels having moderate readiness levels. Furthermore, the variable level of education is on average at a moderate level of readiness, with the education level of SMA / equivalent having the highest percentage of $88.9 \%$ (8 respondentss), then the doctoral education level with a percentage of $60 \%$ (12 respondentss).

According to Holt, et al. (2007) Change-Specific Efficacy refers to the level of individual belief that they have the ability and skills to carry out tasks and activities when change is implemented. In this dimension, both positions already have the confidence that the abilities and skills obtained from education, training, and experience can be implemented properly following the changes that occur. In the Age Variable, in this dimension, the age $<20$ years is more dominant in terms of having confidence in the ability and skills in running WFH. On the one hand, if you look at the education variables, SMA / equivalent, and Doctoral education are more dominant in this dimension.

Civil servants feel confident that they can run WFH with their abilities and skills because during WFH CIVIL SERVANTS is also provided with online seminars or what are known as webinars. One of them is ASN Inspiration Talk which is a discussion forum organized by the Ministry of Administrative Reform and Bureaucratic Reform (PANRB) to 
increase the insight and skills of ASN with different themes each week (Menpanrb Humas, 2020). According to Makarius and Larson (2017), a virtual worker must be able to increase other people's confidence in their abilities, by showing competence in tasks and demonstrating their skills. That way, believing in the abilities and skills possessed is important in seeing the readiness for change.

Table D.

Dimensions of Personal Valence for Three Variables (Position, Age, and Last Education Level)

\begin{tabular}{|c|c|c|}
\hline $\begin{array}{c}\text { Variable of Civil Servants } \\
\text { Position }\end{array}$ & \multicolumn{2}{|c|}{ Readiness Level } \\
\hline \multirow[t]{3}{*}{ Functional Position } & Low & $8,8 \%$ \\
\hline & Medium & $79,6 \%$ \\
\hline & High & $11,5 \%$ \\
\hline \multirow[t]{3}{*}{ Structural Position } & Low & $9,6 \%$ \\
\hline & Medium & $70,1 \%$ \\
\hline & High & $20,4 \%$ \\
\hline $\begin{array}{c}\text { Variable of Age } \\
\quad(n=383)\end{array}$ & \multicolumn{2}{|c|}{ Readiness Level } \\
\hline \multirow{3}{*}{$<20$ years } & Low & $0 \%$ \\
\hline & Medium & $100 \%$ \\
\hline & High & $0 \%$ \\
\hline \multirow{3}{*}{$20-30$ years } & Low & $12,7 \%$ \\
\hline & Medium & $63,5 \%$ \\
\hline & High & $23,8 \%$ \\
\hline \multirow{3}{*}{$31-40$ years } & Low & $6 \%$ \\
\hline & Medium & $77,8 \%$ \\
\hline & High & $16,2 \%$ \\
\hline \multirow{3}{*}{ 41-50 years } & Low & $10,4 \%$ \\
\hline & Medium & $72,6 \%$ \\
\hline & High & $17 \%$ \\
\hline \multirow{3}{*}{$51-60$ years } & Low & $9,7 \%$ \\
\hline & Medium & $84,9 \%$ \\
\hline & High & $5,4 \%$ \\
\hline \multirow{3}{*}{$>60$ years } & Low & $0 \%$ \\
\hline & Medium & $66,7 \%$ \\
\hline & High & $33,3 \%$ \\
\hline Variable of last education & \multicolumn{2}{|c|}{ Readiness Level } \\
\hline
\end{tabular}




\begin{tabular}{|c|l|c|}
\hline \multicolumn{1}{|c|}{$(\mathbf{n = 3 8 3 )}$} & \multicolumn{2}{|c|}{} \\
\hline \multirow{3}{*}{ SMA/Sederajat } & Low & $11,1 \%$ \\
\cline { 2 - 3 } & Medium & $88,9 \%$ \\
\cline { 2 - 3 } & High & $0 \%$ \\
\hline \multirow{3}{*}{ Diploma (D1/D2/D3) } & Low & $8,7 \%$ \\
\cline { 2 - 3 } & Medium & $69,6 \%$ \\
\cline { 2 - 3 } & High & $21,7 \%$ \\
\hline \multirow{3}{*}{ Sarjana/D4 } & Low & $10,2 \%$ \\
\cline { 2 - 3 } & Medium & $76,9 \%$ \\
\cline { 2 - 3 } & High & $12,9 \%$ \\
\hline \multirow{3}{*}{ Magister } & Low & $7,6 \%$ \\
\cline { 2 - 3 } & Medium & $74,5 \%$ \\
\cline { 2 - 3 } & High & $17,9 \%$ \\
\hline \multirow{3}{*}{ Doktor } & Low & $10 \%$ \\
\cline { 2 - 3 } & Medium & $75 \%$ \\
\cline { 2 - 3 } & High & $15 \%$ \\
\hline
\end{tabular}

Source: Results of research data processing, 2020

Based on the processed results of the researcher's survey which can be seen in Table $\mathrm{D}$, the last dimension Personal Valence gets moderate results on the three Demographic Variables (position, age, and education level). In this dimension, the Position Variables (Functional and Structural) are both at the moderate level in carrying out WFH, namely 180 respondentss (79.6 percent) in Functional Positions and 110 respondentss (70.1 percent) in Structural Positions. Age variables in this dimension are also all at a moderate level, with age $<20$ years having a high percentage of $100 \%$ ( 2 respondentss). Then, in the variable level of education, high school/equivalent and doctorate dominates with the respective percentage, $88.9 \%$ (8 respondentss), and 75\% (15 respondentss).

According to Holt, et al. (2007) Personal Valence refers to the level of individual confidence that the proposed changes are beneficial for individuals personally. In this dimension, the results show that the three influential demographic variables, namely position, age, and education level, feel that change is beneficial for individual personalities. The benefits felt by individual civil servants can be seen from semi-open questions that focus on communication with internal and external parties during WFH which can be said to be running smoothly, from these results as many as 281 respondentss $(73.4 \%)$ answered that they did not experience obstacles in establishing communication with internal parties (such as colleagues, superiors), while to experience obstacles in establishing communication with external parties, 274 (71.5\%) of respondentss answered that they did not experience obstacles. 
With these results, the three variables, both occupation, age, and education level were equally able to communicate fluently, because it was felt that WFH had personal benefits for individual civil servants.

The benefits that can be felt by individual civil servants during WFH are the creation of a work-life balance, but of course, they must apply time discipline so that work targets can be achieved properly and time for family and other needs can still run in a balanced manner (Rizky, 2020). Furthermore, Mustajab, et al. (2020) stated that there are several positive impacts from WFH, namely Work-Life Balance, Flexibility, Saving Time, Quality Time, and Comfortable. According to the Ministry of Administrative and Bureaucratic Reform (PANRB), the presence of WFH has increased the ability of employees to utilize information technology and also work-life balance (Prabowo, 2020). Changing the work system to WFH has many benefits for civil servants, although not all of the benefits are fully felt.

\section{Conclusion}

This study aims to investigate the influence of four demographic factors possessed by civil servants (structural / functional position, age, last education level, and length of work) on their level of readiness in implementing work from home policies. The results of the analysis show that three demographic factors are statistically proven to have an influence on the readiness level of civil servants. First, civil servants who occupy structural positions have a better level of readiness than their colleagues who hold functional positions ( $1 \%$ confidence level). Second, the age factor of civil servants is proven to have an inverse effect on the readiness level of civil servants, namely that younger civil servants are more prepared to work from home. In addition, the higher the level of education possessed by individual civil servants, the higher their level of readiness. The last two factors (age and education level) are significant at the $10 \%$ confidence level. The long working time factor has no effect on the readiness of civil servants in implementing the work from home policy.

Practically, the findings in this study can be used as input for policy makers in determining the direction of policies related to WFH in civil servants in the future. These three factors can become criteria in developing a supporting system to support the productivity of civil servants who are allowed to work from home. Although this study has limitations in the number of respondentss involved, it can be a starting point to further explore why civil 
servants with structural positions, younger and highly educated have a higher or greater potential to run WFH productively. We encourage follow-up studies with a more representative number of respondentss as well as the use of other theoretical frameworks to increase our understanding of the issue of civil servants working from home.

\section{Acknowledgment}

Thank you to the MPA Class 1 (Teachers and Students), Faculty of Administrative Sciences, Universitas Indonesia for allowing the use of primary data regarding the readiness of civil servants in carrying out WFH policies for further processing as the basis for the analysis of this study.

\section{References}

\section{Journal Article}

Armenakis, Achilles A; Harris, Stanley G; Mossholder, Kevin W. Creating readiness for organizational change. Human Relations ; Thousand Oaks, Vol. 46, Iss. 6, (Jun 1993): 681.

Armenakis, A. A., Harris, S. G., \& Mossholder, K. W. (1993). Creating Readiness for Organizational Change. Human Relations Vol 46 No. 6, 681-703.

Bernerth, Jeremy. Expanding Our Understanding of the Change Message. Human Resource Development Review, Vol. 3, No. 1 March 2004 36-52.

Bick,Alexander, Adam Blandin, and Karel Mertens. (2020). Work from Home After the COVID-19 Outbreak.

Bronen, R., \& Chapin, S. (2013). Adaptive governance and institutional strategies for climateinduced community relocations in Alaska. Proceedings of the National Academy of Sciences of the United States of America, 110(23), , 9320-9325.

Caillier, J. G. (2012). The Impact of Teleworking on Work Motivation in a U.S. Federal Government Agency. American Review of Public Administration, 42(4), 461- 480.

Fonner, K. L., \& Roloff, M. E. (2010). Why Teleworkers are More Satisfied with Their Jobs than are Office-Based Workers: When Less Contact is Beneficial. Journal of Applied Communication Research Vol.38 No.4, 336-361. 
Holt, D. T., Armenakis, A. A., Feild, H. S., \& Harris, S. G. (2007). Readiness for Organizational Change: The Systematic Development of a Scale. The Journal of Applied Behavioral Science Vol. 43 No. 2, 232-255.

Holt, D. T., \& Vardaman, J. M. (2013). Toward a Comprehensive Understanding of Readiness for Change: The Case for an Expanded Conceptualization. Journal of Change Management, Vol. 13 No. 1, 9-18.

Hynes, M. (2014). Telework Isn't Working: A Policy Review. The Economic and Social Review, Vol. 45, No. 4, 579-602.

Jansen, M., \& Voort, H. V. (2016). Adaptive governance: Towards a stable, accountable and responsive government. Government Information Quarterly Vol 33 (1), 1-5.

Janssen, M., \& Voort, H. v. (2020). Agile and adaptive governance in crisis response: Lessons from the COVID-19 Pandemic. International Journal of Information Management, 1-7.

Makarius, Erin E., \& Larson, Barbara Z.. (2017). Changing The Perspective Of Virtual Work: Building Virtual Intelligence At The Individual Level. Academy of Management Perspectives, Vol. 31, No. 2, 159-178.

Mustajab, Duta, dkk. (2020). Working from Home Phenomenon as an Effort to Prevent COVID-19 Attacks and Its Impacts on Work Productivity. The International Journal of Applied Business, 4(1): 13-21.

Nakrošienė, A., Bučiūnienė, I., \& Goštautaitė, B. (2019). Working from home: characteristics and outcomes of telework. International Journal of Manpower, 1-16.

Rafferty, Alannah E., et al. (2013). Change Readiness: A Multilevel Review. Journal of Management, Vol. 39 No. 1, 110-135.

Rakhmawanto, Ajib. (2007). Seleksi Pengangkatan Pegawai Negeri Sipil Dalam Jabatan Struktural. Jurnal kebijakan dan Manajemen CIVIL SERVANTS, Vol.1, No.2, November. Rohida, Leni, Nuryanto, Yayan dan Sarif. (2018). Implementasi Pengalihan Jabatan Struktural Ke Jabatan Fungsional Melalui Inpassing/Penyesuaian (Studi Kasus Di Universitas Padjadjaran). Civil Service, Vol. 12, No.1, 11 - 22.

Rupiettaa, Kira and Michael Beckmannb. (2016). Working from Home - What is the Effect on Employees' Effort?. Center of Business and Economics (WWZ) Working Paper 2016/07, University of Base. 
Singh, P., R. Paleti, S. Jenkins, and C.R. Bhat. (2013), "On Modeling Telecommuting Behavior: Option, Choice, and Frequency," Transportation, Vol. 40, No. 2, pp. 373-396.

Stratigea, A., \& Giaoutzi, M. (2000). Teleworking and Virtual Organization in the Urban and Regional Context. NETCOM, 331-357.

Suarlan. (2017). Teleworking for Indonesian Civil servants: Problems and Actors. International Journal of Administrative Science \& Organization Vol 24, No.2, 100-109.

Vries, H. d., Tummers, L., \& Bekkers, V. (2019). The Benefits of Teleworking in the Public Sector: Reality or Rhetoric? Review of Public Personnel Administration vol 24 no.4, 570-593.

Vries, H. d., Tummers, L., \& Bekkers, V. (2018). A Stakeholder Perspective On Public Sector Innovation:Why Position Matters. International Review of Administrative Sciences, 269287.

Walls, Margaret \& Safirova, Elena \& Jiang, Yi. (2006). What Drives Telecommuting? The Relative Impact of Worker Demographics, Employer Characteristics, and Job Types. Transportation Research Record Journal of the Transportation Research Board. 2010. 10.3141/2010-13, pp. 111-120.

Zhang, S., Moeckel, R., Moreno, A. T., Shuai, B., \& Gao, J. (2020). A work-life conflict perspective on telework. Transportation research. Part A, Policy and practice, 141, 5168. https://doi.org/10.1016/j.tra.2020.09.007.

\section{Website}

Cahyana, Mulyana. (2020). Mendadak WFH, Banyak ASN Belum Siap dan Berimbas ke Pelayanan. Retrieved from: https://mediaindonesia.com/read/detail/303640mendadak-wfh-banyak-asn-belum-siap-dan-berimbas-ke-pelayanan

Dewayani, T. (2020, Maret 31). Bekerja dari Rumah (Work From Home) Dari Sudut Pandang Unit Kepatuhan Internal. Diambil kembali dari DJKN Kemenkeu: https://www.djkn.kemenkeu.go.id/artikel/baca/13014/Bekerja-dari-Rumah-WorkFrom-Home-Dari-Sudut-Pandang-Unit-Kepatuhan-Internal.html

Fajar, T. (2019). Kemenpan RB Wacanakan CIVIL SERVANTS Bisa Kerja di Rumah. OKEfinance. https://economy.okezone.com/read/2019/08/08/320/2089595/kemenpanrb- wacanakan-Civil servants-bisa-kerja-di-rumah 
Gloria. (2020, September 10). Sistem Kerja WfH Akan Berdampak pada Pelayanan Publik. Diambil kembali dari ugm.ac.id: https://ugm.ac.id/id/berita/20034-sistem-kerja-wfhakan-berdampak-pada-pelayanan-publik

Humas MENPANRB. (2020). Tingkatkan Produktivitas ASN Selama WFH, Kementerian PANRB akan Gelar Bincang Inspirasi ASN. Retrieved from: https://menpan.go.id/site/berita-terkini/tingkatkan-produktivitas-asn-selama-wfhkementerian-akan-gelar-bincang-inspirasi-asn

Idris, Muhammad. (2020). Mengenal Jenjang Karir Bagi Seorang CIVIL SERVANTS. Retrieved from: https://money.kompas.com/read/2020/03/08/132255326/mengenal-jenjang-karirbagi-seorang-Civil servants?page=all

KASN.go.id. (2020, Mei 15). Birokrasi selama Masa Pandemi. Diambil kembali dari KASN.go.id: $\quad$ https://www.kasn.go.id/details/item/570-birokrasi-selama-masapandemi

KPMG. (2020). The new reality for government: Post-pandemic global insights for the public sector. Diambil kembali dari https://home.kpmg/xx/en/home/industries/governmentpublic-sector/the-new-reality-for-government/human-resources.html

Kusnandar, Viva Budy. (2020). Berapa Jumlah Penduduk Usia Produktif Indonesia?. Retrieved from: https://databoks.katadata.co.id/datapublish/2019/09/09/berapajumlah-penduduk-usia-produktif-indonesia\#

Krisyohana, Mida. (2020). Kesiapan Manajemen ASN untuk WFH. Retrieved from: https://news.detik.com/kolom/d-5049198/kesiapan-manajemen-asn-untuk-wfh

Lidyana, Vadhia. (2020). Awas! CIVIL SERVANTS yang Tak Produktif Bisa Dimutasi. Retrieved from: https://finance.detik.com/berita-ekonomi-bisnis/d-5061802/awasCivil servants-yang-tak-produktif-bisa-dimutasi/2

Mariskan, D. (2020, Juni 26). Gov't Prepares for 'Adaptive Bureaucracy' Post-Pandemic. Diambil kembali dari jakartaglobe.go.id: https://jakartaglobe.id/news/govt-preparesfor-adaptive-bureaucracy-postpandemic

menpan.go.id. (2020, April 23). Aplikasi SIPP Kembangkan Fitur Baru Terkait Layanan Publik Selama Pandemi Covid-19. Diambil kembali dari menpan.go.id: 
https://menpan.go.id/site/berita-terkini/aplikasi-sipp-kembangkan-fitur-baru-terkaitlayanan-publik-selama-pandemi-covid-19

Prabowo, Dani. (2020). Evaluasi WFH ASN, Ini Manfaatnya Menurut Menpan RB Tjahjo Kumolo. Retrieved from: https://nasional.kompas.com/read/2020/04/03/18015061/evaluasi-wfh-asn-inimanfaatnya-menurut-menpan-rb-tjahjo-kumolo.

Rizky, Adrian Yanuwar. (2020). Kerja Dari Rumah, Memungkinkan Bagi ASN?. Retrieved from: $\quad$ https://kumparan.com/adrian-yanuwar-rizky/kerja-dari-rumahmemungkinkan-bagi-asn-1tajHmt3bDK/full

Setiadi, Agus. (2020, April 20). Covid-19: Perubahan Pola Kerja dan Pola Hidup CIVIL SERVANTS. Diambil kembali dari palembang.bkn.go.id: https://palembang.bkn.go.id/covid-19-perubahan-pola-kerja-dan-pola-hidup-Civil servants/

Sugianto, D. (2020, Juni 7). Cara Kerja CIVIL SERVANTS Dibuat Fleksibel saat New Normal. Diambil kembali dari Detikfinance: https://finance.detik.com/berita-ekonomibisnis/d-5043739/cara-kerja-Civil servants-dibuat-fleksibel-saat-new-normal

Ritchie, H., \& Roser, M. (2020, May 7). Policy Responses to the Coronavirus Pandemic. Diambil kembali dari ourworldindata.org: https://ourworldindata.org/policyresponses-covid

Shalihah, N. F. (2020, September 21). Bantuan Pulsa untuk CIVIL SERVANTS Kemenkeu, Benarkah Rp 200.000? Ini Faktanya. Diambil kembali dari kompas.com: https://www.kompas.com/tren/read/2020/08/21/183000365/bantuan-pulsa-untuk-

Civil servants-kemenkeu-benarkah-rp-200.000-ini-faktanya?page=all

tanotofoundation.org. (2020, Juni 26). Pandemi Covid-19 Sebagai Momentum untuk Reformasi Birokrasi. Diambil kembali dari tanotofoundation.org: https://tanotofoundation.org/id/news/pandemi-covid-19-sebagai-momentum-untukreformasi-birokrasi/

TheAsean. (2020). Preparing ASEANS's Wokforce For The Future of Work. The Asean Issue 4,4 .

\section{Legislation and Publication of the Institute}

Undang-Undang Nomor 5 Tahun 2014 tentang Aparatur Sipil Negara 
Peraturan Pemerintah Republik Indonesia Nomor 11 Tahun 2017 Tentang Manajemen Pegawai Negeri Sipil

Badan Kepegawaian Negara. (2020). Buku Statistik CIVIL SERVANTS Juni 2020. 